\title{
Managing biotic interactions for ecological intensification of agroecosystems
}

\author{
Sabrina Gaba ${ }^{1 *}$, François Bretagnolle ${ }^{2,3}$, Thierry Rigaud ${ }^{2}$ and Laurent Philippot ${ }^{1}$ \\ 1 Institut National de la Recherche Agronomique, UMR1347 Agroécologie, Dijon, France \\ ${ }^{2}$ Laboratoire Biogéosciences, Equipe Ecologie Evolutive, UMR CNRS 6282, Université de Bourgogne, Dijon, France \\ ${ }^{3}$ UMR 5175 Centre d'Écologie Fonctionnelle et Évolutive-CNRS, Montpellier, France
}

Edited by:

Gary D. Bending, University of

Warwick, UK

Reviewed by:

Vesna Gagic, Swedish University of Agricultural Sciences, Sweden

Aidan M. Keith, Centre for Ecology

and Hydrology, UK

*Correspondence:

Sabrina Gaba, Institut National de la

Recherche Agronomique, UMR1347

Agroécologie, 17 Rue Sully, F-21065

Dijon Cedex, France

e-mail: sabrina.gaba@dijon.inra.fr
Agriculture faces the challenge of increasing food production while simultaneously reducing the use of inputs and delivering other ecosystem services. Ecological intensification of agriculture is a paradigm shift, which has recently been proposed to meet such challenges through the manipulation of biotic interactions. While this approach opens up new possibilities, there are many constraints related to the complexity of agroecosystems that make it difficult to implement. Future advances, which are essential to guide agricultural policy, require an eco-evolutionary framework to ensure that ecological intensification is beneficial in the long term.

Keywords: agroecology, pest control, land use, adaptation, ecosystem services, biodiversity

\section{INTRODUCTION}

The manipulation and regulation of biotic interactions and the functioning of agroecosystems in order to increase agricultural production sustainably while maintaining the diverse services provided by these ecosystems is the major challenge of the Twenty first century. Agricultural lands are more complex and diverse ecosystems than pictured in the classical cliché. Most of this biodiversity is hidden in the soil, with up to $10^{7}$ prokaryotes per gram of soil and at least $10^{5}$ bacterial species (Torsvik et al., 1990; Whitman et al., 1998; Gans, 2005), and agroecosystems also host insects, weeds, birds and rodents, leading to complex interactions and trophic networks (Figure 1). Managing interactions between and within the different trophic levels may enhance agroecosystem functions and increase crop productivity and improve pest control and sustainability (Mcneely and Scherr, 2003; Bommarco et al., 2013; Tixier et al., 2013a). For example, interactions between belowground soil organisms and aboveground plant communities influence ecosystem processes and properties with consequences for the provision of the related services (Bardgett et al., 2005). The direct management of biotic interactions such as the use of microbial strains to promote plant growth (Shennan, 2008; Doré et al., 2011; Ekstrom and Ekbom, 2011) and the enhancement of services that ecosystems provide naturally, such as pest control, underlies the ecological intensification of cropping systems (Figure 2). Given its potential as an alternative to chemical intensification, interest in ecological intensification has been growing, both in ecological and agronomic research (Cassman, 1999; Bommarco et al., 2013; Garnett et al., 2013). However, current research often relies on the manipulation of interactions between a small number of species, for example a pest and its predator, even though these interactions are part of a complex network. This overlooks (i) the possible resulting trophic cascades within the network, (ii) the possible eco-evolutionary responses of the species in the network, and (iii) the resistance and resilience of the ecosystem.

In this review, we argue that, whatever the methods used for ecological intensification (e.g., direct management of biotic interactions or intensification of the biological processes supporting ecosystem services), there is a need for a deeper understanding of biological interactions within agroecosystems to avoid techniques that are ineffective or, worse, have negative impacts that outweigh the benefits to the services. Such knowledge would gain to be investigated within an eco-evolutionary framework, to explore effects in the medium term (effectiveness of the management techniques) and the long term (sustainability of the management techniques). This would also allow taking advantage of the possibilities provided by complex ecological modeling (e.g., network models in the widest sense from food webs to landscape networks which take account of complex ecological properties to test management strategies, Tixier et al., 2013b). The management of the multiple services delivered by agroecosystems and of the corresponding trade-offs has recently been addressed by Bommarco et al. (2013), while Tscharntke et al. (2012) outlined the shortcomings of a dichotomic view between land sharing and land sparing for real world application. In this review, we focus on how to ensure the effectiveness and sustainability of ecological intensification. After introducing the different definitions of ecological intensification, we present significant achievements in the field. We then suggest a conceptual framework for successful management of biotic interactions. Finally, we discuss approaches and tools for practical applications of ecological intensification.

\section{DEFINITIONS OF ECOLOGICAL INTENSIFICATION}

The term "ecological intensification" is relatively recent and there is still no generally accepted meaning (Garnett et al., 2013). 


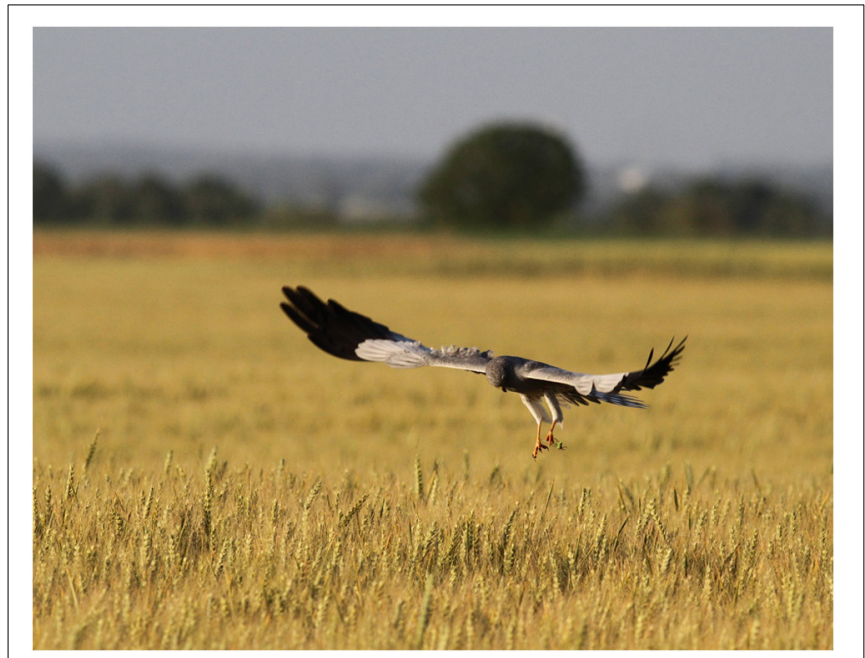

FIGURE 1 | Picture of a Montagu's harrier (Circus pygargus) hunting a big green grasshopper in a wheat field in the Long Term Ecological Research Network site "Plaine et Val de Sèvre" (Photo: V. Bretagnolle). This shows that agricultural farmlands provide a suitable habitat for species other than the main crop, opening up new possibilities for resource and pest control by using the natural functions of farmland biodiversity.

"Ecological intensification" was originally defined as the process of increasing crop production to satisfy future food demand while meeting acceptable standards of environmental quality (Cassman, 1999, 2008; Garnett et al., 2013). Its aim is to maximize the primary production per unit area without compromising the ability of the system to sustain its productive capacity. However, ecological intensification can be more than simply a form of agricultural intensification that preserves the environment by making best use of environmental goods and services (Pretty, 2008; Bonny, 2011). It is based on management of ecosystem processes rather than fossil fuel inputs by (i) integrating biological and ecological processes into food production processes and (ii) minimizing the use of non-renewable inputs. In this sense, "ecological intensification" of agriculture is based on the principles of persistence and resilience of the agroecosystem and the principle of autarchy, i.e., the capacity to deliver outputs from inputs and resources acquired from within the system boundaries (Pretty, 2008; Power, 2010). One way to maximize production through ecological intensification is to manage organisms providing regulation services such as pest control, pollination and soil nutrients (Bommarco et al., 2013).

More recently, "ecological intensification" has been placed in the broader concept of ecological engineering which is the use of ecological science and theory to design, construct and manage ecosystems to benefit both humanity and nature (Mitsch and Jorgensen, 2003). One of the key principles of this paradigm is to integrate biological and ecological processes into food production, focusing on the agricultural system and landscape design. It relies on the premise that natural ecosystems may provide good models for designing agricultural systems that match environmental, social and sustainability objectives.

\section{MANAGING BIOTIC INTERACTIONS: SUCCESSES AND POTENTIAL}

Ecological intensification aims to promote beneficial biological interactions to limit the massive use of chemical inputs such as pesticides and fertilizers and to reduce the environmental impact. A conventional approach for decreasing pesticide use is based on antagonistic interactions between pests and their natural enemies. One of the flagship successes of such biological control in crops was the release of the parasitoïd Encarsia formosa against the greenhouse whitefly Trialeurodes vaporariorum in the 1970s as a substitute for pesticides to which the whitefly had evolved to be resistant (Hoddle et al., 1998; Bale et al., 2008). The importance of antagonistic interactions in crop fields is illustrated by the so called "disease-suppressive soils" in which crop plants suffer less from certain diseases even though the virulent soil-borne pathogens are present. In these soils, interactions between the pathogens and the indigenous soil microorganisms are responsible for reducing the severity of the disease by inhibiting the growth or activity of the pathogen (Mendes et al., 2011). The potential for biocontrol of diseases by using interactions such as amensalism (e.g., antibiosis), competition and parasitism between fungal or bacterial strains and plant pathogens has been widely studied in microbial ecology (Haas and Defago, 2005; Harman, 2006; Philippot et al., 2013a).

Similarly, positive interactions such as facilitation and mutualism can also help to reduce fertilizer inputs and increase primary production. In an intercropped agroecosystem, the exudation of phosphorous-mobilizing compounds or other mechanisms for increasing phosphate availability by one species can facilitate phosphorous uptake by the other species (Hinsinger et al., 2011). Saprophytic microorganisms thriving in the rhizosphere also increase soil resource availability by cycling nutrients, which is beneficial for the plants. Plant growth promoting rhizobacteria (PGPR), which are commonly applied in developing countries where the use of mineral fertilizer is limited by costs, can also trigger growth by synthesizing volatiles mimicking plant hormones (Ryu et al., 2003). Managing plant-microbe interactions is of interest not only for optimizing nutrient cycling but also for reducing consequences such as leaching and greenhouse gas emissions. It has recently been demonstrated that compounds inhibiting the microbial oxidation of ammonium into nitrate released by plant roots resulted in reduced field emissions of $\mathrm{N}_{2} \mathrm{O}$ (Subbarao et al., 2009). Selection for such traits may lead to a new generation of crop cultivars that limit microbial emissions of greenhouse gases (Philippot and Hallin, 2011).

\section{PROMOTING BIODIVERSITY TO ENSURE SUSTAINABILITY}

Promoting biodiversity in agroecosystems can increase their sustainability in various ways. Firstly, it is now evident that biodiversity is important for ecosystem functioning and this has been demonstrated for several communities (Isbell et al., 2011; Cardinale et al., 2012). In an early study, Tilman et al. (1996) showed that plant productivity increased with plant species richness. Similarly, predator diversity strengthens pest control of either single or multiple species of prey (Snyder et al., 2008; Takizawa and Snyder, 2011) and plant diversity can have beneficial effects on pest control by encouraging the natural enemies 


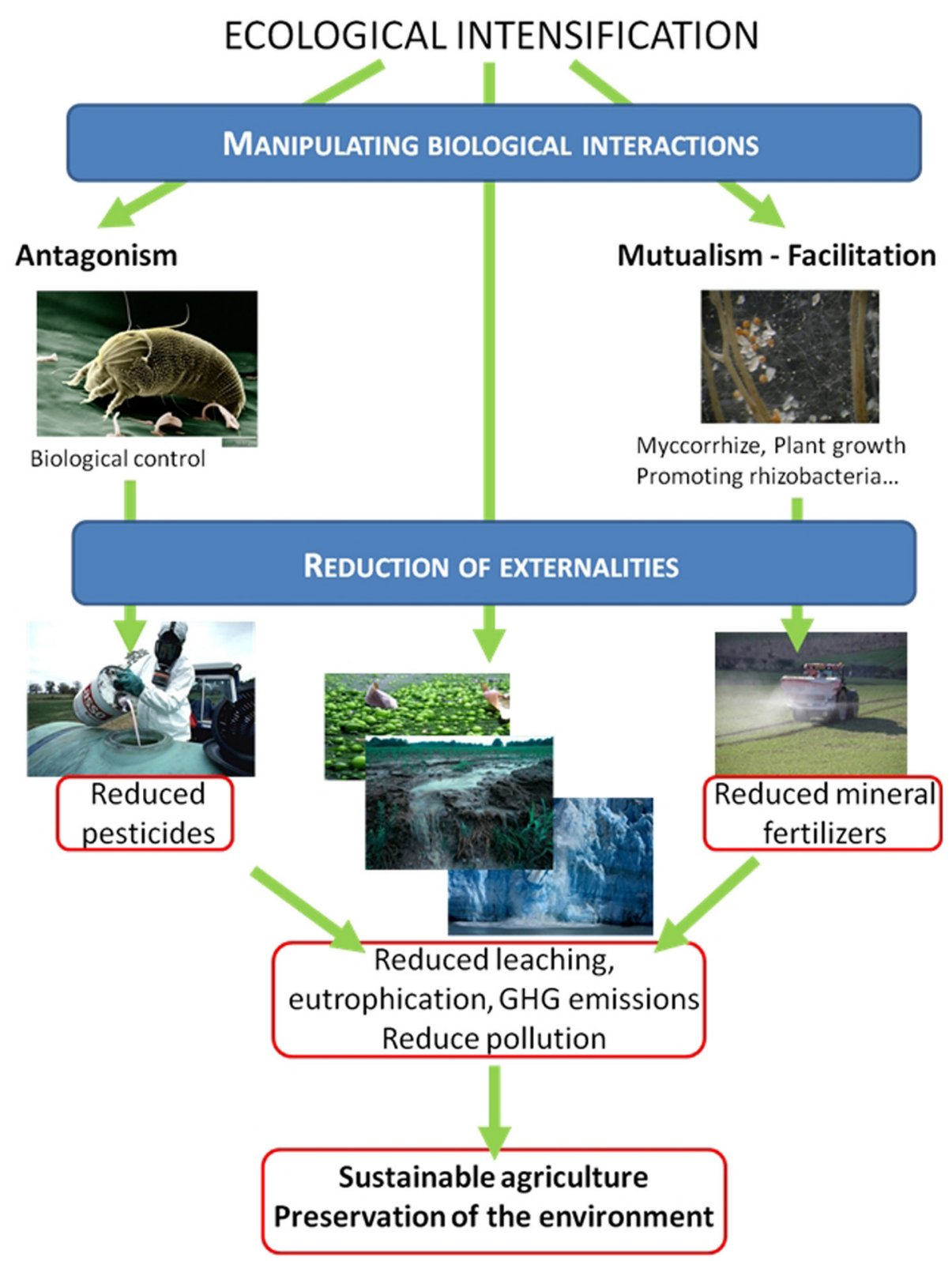

FIGURE 2 | Possible means (blue frames) and objectives (red frames) of ecological intensification.

of crop pests, either because non-crop plants increase the number and diversity of enemies (Perdikis et al., 2011) or because they increase the number of links in the food (or interaction) webs. In this second case, an increased number of links increases the stability of networks including natural enemies, thus reducing the risk of enemy extinction (Macfadyen et al., 2011). Diversifying cropping systems with non-crop species may improve top-down control of natural herbivores. In a recent paper, Balmer et al. (2013) found that non-crop flowering plants planted within or around Brassica oleracea fields had a significant effect on the complex plant-herbivore-parasitoid-predator food web through the increased rate of parasitism and predation on the target cabbage pest species. Plant production can also be affected by microbial community composition and diversity (Wardle et al., 2004; Maherali and Klironomos, 2007). It was also demonstrated experimentally that microbial diversity loss was detrimental to the cycling of nitrogen, a nutrient essential for plant growth (Philippot et al., 2013b), and that rare soil microbes may play a role in crop protection by improving aboveground and belowground plant defenses (Hol et al., 2013). Secondly, it is argued that increased biodiversity can also "insure" ecosystems against decline in functioning under fluctuating conditions, thus increasing ecosystem stability (Yachi and Loreau, 1999). This "insurance hypothesis" is based on the intuitive concept that the probability of finding species able to adapt to changing conditions and allowing ecosystem functioning is greater in a more diverse ecosystem. 
Decreased soil biodiversity reduces the resilience of organic matter decomposition to a disturbance caused by adding copper (Griffiths et al., 2000). Furthermore, manipulation of both richness and evenness of a microbial guild involved in nitrogen cycling showed that its resistance to salinity disturbance was lower when the initial communities were very uneven or dominated by a few species, suggesting that evenness can also be important for ecosystem stability (Wittebolle et al., 2009). Finally, it was suggested that the influence of biodiversity on ecosystem functioning and stability depends on the strength of the interactions between species (May, 1972; Rooney and Mccann, 2011). Compartmentalized trophic networks, which consist of groups of species that have a higher probability of interacting with each other rather than with species of other groups, showed increased stability against perturbation (Stouffer and Bascompte, 2011). The type of interaction is also important since, in contrast to trophic networks, stability is increased by a densely connected, nested structure in mutualistic networks (Thebault and Fontaine, 2010).

While increasing biodiversity is a promising way of enhancing biotic interactions to reduce the use of chemical inputs, the trade-offs and synergies of these biotic interactions are rarely quantified. For example, complementarity between predators and niche partitioning is often suggested as an explanation of the higher success of a diversity of predators on resource consumption (e.g., Northfield et al., 2010) and, by extension, pest control. However, increasing the diversity of predators may increase the frequency of intraguild predator species and, therefore, diminish the effectiveness of pest control through predator-predator interactions (e.g., Schausberger and Walzer, 2001). Furthermore, although increasing plant diversity can be translated into better pest control, it is often less effective than intensive chemical treatment (e.g., Brown, 2012), leading to a significant decrease in the overall crop yields (Letourneau et al., 2011). Therefore, a better knowledge of the network properties is still needed to understand the relationship between complexity and ecological stability (Montoya et al., 2006) and to make efficient use of increased biodiversity as an ecological service.

\section{IMPORTANCE OF THE SPATIAL SCALE AND LANDSCAPE ORGANIZATION FOR BIOTIC INTERACTION MANAGEMENT}

The surrounding biotic (i.e., all organisms present in the surrounding habitats) and abiotic (i.e., landscape use, composition and structure) environments of arable fields affect the magnitude of biotic interactions. For example, the crop pollination service provided by native bees depends on the proportion of upland natural habitat surrounding a farm (Kremen et al., 2004). The coexistence of ruderal plants and crops can also increase crop yield by changing the community composition of pollinators (Carvalheiro et al., 2011). The majority of natural enemies are generalist predators that require non-crop habitats to various extents for reproduction sites, alternative food sources or refuges. A wide range of approaches have been proposed to increase the abundance and diversity of the natural enemy community, including habitat and landscape manipulation and food supplementation (Chaplin-Kramer et al., 2011). However, it has proved difficult to assess the contribution of local and landscape factors to pest abundance and to the level of biological control and has led to inconsistent findings (Thies and Tscharntke, 1999; Bianchi et al., 2006; Chaplin-Kramer et al., 2011; Veres et al., 2011). Moreover, even though some studies have explored the question of the scale at which biodiversity is important for ecosystem functioning, many gaps remain mainly because many control agents such as arthropods can disperse not only at local scale (i.e., between non-crop habitats and crops) but also at landscape scale (between different crops or different non-crop habitats). A study focusing on two potato pests revealed that predation occurred over different scales for each pest and that its intensity varied with the habitat type: predation on beetle eggs increased in crop and non-crop habitats when field margins were large relative to the potato fields, whereas aphid predation in field margins increased over a small scale with the area of non-crop habitats but did not change in adjacent potato fields (Werling and Gratton, 2010). Therefore, a better knowledge of these interactions is required to understand changes in predator and parasitoïd communities, non-target effects, effects over different spatial scales (local vs. landscape scales), context-dependent responses and temporal stability of the effects.

\section{AGRICULTURAL OBJECTIVES AND POPULATION DYNAMICS}

In agroecosystems, land use distribution has a high turn-over, resulting in strong spatiotemporal variations in food resources for pests. However, a recent meta-analysis revealed that most studies were carried out over a time scale as short as a single sampling season, which is unsuitable for predicting the results of trophic interactions and, therefore, for proposing management strategies (Herrera and Doblas-Miranda, 2013). This is even more likely since a time-lag is often observed in the response of species to predation, competition or parasitism (Wangersky and Cunningham, 1957) or to changes in land use (Jonason et al., 2011) and climate (Menendez et al., 2006). A time-lag is, therefore, to be expected when manipulating biotic interactions through ecological intensification and its duration is likely to depend on a multitude of factors such as species dynamics, the strength of the biotic interaction (generalist vs. specialist) and the landscape context. For instance, a specialist predator will provide efficient control of a prey in the medium term whereas a generalist predator would provide more rapid but less efficient control (Hanski and Woiwod, 1991; Symondson et al., 2002). The question arises of whether the timing of the response of biological control is compatible with agricultural objectives (e.g., crop yield and farm income) or whether there would be too great an offset in the timing of the control by ecological processes and the change in management system hence limiting potential benefits. Understanding the mechanisms underlying the timing of the response of species after management change is essential for use of ecological intensification by farmers.

\section{ECO-EVOLUTIONARY PROCESSES IN AGROECOSYSTEMS}

Organisms are able to adapt to rapid environmental changes and to counteract strong selection pressure. Strong selection and rapid evolutionary changes have been shown in antagonistic interactions such as host-parasite relationships (Decaestecker et al., 2007; Koskella and Lively, 2007). Similarly, rapid natural selection of resistance to pesticides has been shown in various crops 
and locations (e.g., Rex Consortium, 2013). Consequently, for ecological intensification, the substitution of large-scale chemical selective pressure by a large-scale biotic selective pressure, while avoiding problems of environmental pollution by chemical inputs, could lead to similar problems of pest adaptation. The likelihood that a pest will adapt to its natural enemy and escape the pest control process, which could result in an uncontrolled spread of a pest, is higher if the selective pressure is predictable in time and space (Gilligan, 2008). Including heterogeneity in selection pressures (both in intensity, time and space) could lower the persistence and adaptive potential of pathogens and pests (Gilligan, 2008; Rex Consortium, 2013).

The general idea would be to replace one strong selective pressure by several weaker selective pressures carefully distributed in time and space. For example, pathogens could be controlled by weakening the transmission process of a disease by introducing gaps between susceptible and resistant hosts. One way might be to cultivate a mosaic of different crop species, some being susceptible, some being non-susceptible to the disease, or to apply biocides in a mosaic design (see Gilligan, 2008 for depicting the complexity of mechanisms involved in these strategies). An efficient management strategy should thus be drawn up over landscape and crop succession scales since the taxonomic, functional and genetic diversity of the crops are human-managed. Consequently, the nature of the crop (i.e., as a resource or a host) will vary significantly in both time and space in a non-predictable way, reducing the probability of co-adaptation. For management of agroecosystems based on spatio-temporal heterogeneity, the co-evolutionary process of resistance against the enemy and counter-resistance may lead to a mosaic of local adaptations (Thompson, 2005), creating de facto gaps in the distribution of pests susceptible and resistant to the enemy (e.g., asynchrony in fluctuations in resistance and susceptibility between demes Thrall et al., 2012). This might be a means of controlling the spread of diseases or pests, provided that the life-cycle and life history traits of both partners are known (e.g., dispersal ability Gilligan, 2008). For example, resource concentration techniques which are based on the dilution of the host plant in a crop mixture make a parasite or a pest less efficient in locating and colonizing its host plants (Ratnadass et al., 2012). The emergence of such geographical mosaics of local adaptation supposes that the spatial heterogeneity is maintained over time. This strategy could not only be applied in agro-forestry and in orchards but also in annual crops to create spatio-temporal mosaics.

The benefits provided by biotic interactions may be outweighed by negative feedback within a network. A recent study of an aphid-transmitted viral pathogen showed that an endophytic fungal mutualist reduced aphid attacks on tall fescue but did not reduce the concentration of the virus, although it did help the plant by alleviating the harmful effects of the viral infection (Rua et al., 2013). This means that, although plants appear safe by being resistant to a virus, the potential for viral transmission remains the same. This may result in an increase in viral virulence (as shown by Ebert, 1998): plants with fungi may tolerate higher viral doses, which may be more lethal after their transmission to non-symbiotic plants. Therefore, although it may appear beneficial, protection by a mutualistic symbiont may be detrimental by maintaining the transmission potential of a pathogen. Complex and hidden interactions must be foreseen for successful ecological intensification.

\section{FROM THEORY TO PRACTICE}

Ecological intensification can be achieved in different ways. One of the simplest approaches is to replace current intensive practices, for example large monocultures or massive use of pesticides and fertilizers, by intensified biotic interactions without any other major changes in management strategies. This type of intensification based on the use of one or a few species (e.g., natural enemies of a given pest in a context of large monocultures) needs to be thought through in order to avoid pest adaptation in the medium and long term. The most challenging approach is to "intensify" ecological processes in agroecosystems by encouraging natural biodiversity, particularly biocontrol agents, mutualists and symbionts, with the aim of increasing the effectiveness of beneficial biotic interactions. These approaches require redefining farming systems within a holistic approach to agroecosystems to scale up from plot scale to landscape scale and from agricultural timescales to ecological and evolutionary timescales. For ecological intensification to be widely adopted, a set of methods and tools should be available to address the following questions.

(i) What type of biodiversity (e.g., genetic, species, functional) is required to deliver the ecological services (e.g., resources, pests) for the local targets?

The relationship between biodiversity and ecosystem services should be determined for a variety of socio-economic contexts and environmental conditions. Ecosystem functioning is the result of the local functional diversity, the interaction between species and the interaction between species and the local abiotic conditions. It can be translated into ecosystem services for functions that are important for human well-being (Millennium Ecosystem Assessment, 2005; Constanza et al., 2007; Lamarque et al., 2011). This is illustrated by the conceptual framework proposed by Haines-Young and Potschin (2010), which describes the cascade from biodiversity, functions, services, benefits and values to humans. Although the effects of loss of biodiversity on ecosystem functioning have been widely studied over the past two decades, it is still not easy to establish the links between biodiversity and the provision of valuable ecosystem services (Cardinale et al., 2012). Several functional ecology studies have proposed conceptual frameworks to link biodiversity to ecosystem functions (Lavorel and Garnier, 2002; Diaz et al., 2007). For example, abiotic variables and plant traits rather than land use alone were successfully used by Lavorel et al. (2011) to refine the representation of multiple ecosystem properties and services in a subalpine grassland landscape. Independently, other studies also proposed using diversity indices (e.g., Simpson diversity index, Bateman et al., 2013) to quantify the value of biodiversity as a provider of cultural services. Taking account of the true complexity of food webs is one of the difficult challenges in filling the remaining gaps in the understanding of the 
relationships between biodiversity and ecosystem functioning and services.

(ii) How do management practices, local environment conditions and landscape affect biodiversity?

Surveys and advanced statistical analyses are required to distinguish the effect of each factor on biodiversity and to examine the interactions between them. Datasets should include data on the biodiversity of interest (abundance of pests, microorganisms, etc), management practices (crop type, tillage, pesticide use, sowing date, etc), local environmental conditions ( $\mathrm{pH}$, soil texture, climate, etc) and surrounding biotic (e.g., species richness) and abiotic (landscape composition and structure) environments. Gabriel et al. (2010) recently proposed a novel multi-scale, hierarchical sampling design to account for the effects of farming systems at various scales. However, further study is required to move from the percentage of the variance explained by each group of factors to a full understanding of the ecological processes involved. This could be achieved by translating cropping systems at landscape scale into environmental gradients to allow comparative analysis of very different environmental situations, including situations with very different types of disturbance. Environmental gradients are an excellent way of representing the properties of the environment in order to show how organisms respond to environmental changes (Austin, 1980; Garnier et al., 2007). This approach was recently proposed at field scale (Gaba et al., 2014). This study provides a conceptual framework for characterizing cropping systems on the basis of properties that affect plant performance, i.e., resource and disturbance levels. Cropping system properties have been characterized in three environmental gradients to take account of the system complexity and the relationship between management practices and local conditions, crop types and socio-economic constraints: (1) the local conditions characterizing the site independently of actual land use, such as climatic conditions, soil and past usage, (2) resource availability, and (3) disturbance levels that depend directly on management practices and types of crop. It should be possible to characterize environmental conditions, cropping systems and landscape composition and structure in the same way.

(iii) How, and how rapidly, will organisms adapt to manipulated biotic interactions?

This requires detailed knowledge on the co-evolutionary dynamics of the interacting populations. The consequences of the interplay between major processes (biotic interactions such as competition, mutualism and trophic relationships, the capacity of species to adapt to new conditions, etc) should be explored using eco-evolutionary models. Such models have often shown non-trivial effects of interactions between ecological and evolutionary processes on species dynamics and community patterns (e.g., Kearney et al., 2009; Norberg et al., 2012). For example, Poisot et al. (2012) investigated the functioning of trophic enemy-victim networks and suggested that the temporal variation in the productivity of an environment (i.e., the amount of resources available for the prey) is a major factor in co-evolutionary processes.
This is important in agroecosystems, where the resources are maximized to ensure the production of crop biomass. Using this model, together with a geographical structure approach, would be a promising technique for sustainable control of crops' natural enemies. Since the model explicitly takes account of the frequency of resource input, it can be easily transposed for agricultural systems (the crops being the victim and the pest or disease being the enemy) where the frequency of resource input is under human control.

(iv) How to ensure the effectiveness and sustainability of ecological intensification (i.e., how long does it take for a biotic interaction to be effective)?

The targeted services must be delivered in a timeframe compatible with farmers' expectations (yield and income) in various pedoclimatic and socioeconomic situations. Markov Decision Process (MDP) or Partially Observed Markov Decision Process (POMDP) have been used to propose new management strategies for conservation (Chadès et al., 2008) and agriculture (Tixier et al., 2013b). These mathematical models provide a framework, taking account of the cost-benefit trade-offs, for sequential decision-making when there is a high level of uncertainty. A challenge for ecological intensification in agriculture is to take account of the time-lagged response of populations to biotic interactions in decision making. It is possible to extend this approach to non-Markovian systems taking account of timelagged response (Williams, 2007). A promising approach is to include time-lag in MDP to evaluate whether the application of ecological intensification is compatible with farmers' expectations.

\section{CONCLUSIONS}

Although the potential of ecological intensification is easy to understand, there are many constraints related to the complexity of agroecosystems (multiple organisms, diverse temporal, and spatial scales) which prevent this potential being realized. However, current research themes in ecology and evolution are providing useful concepts and tools which improve our ability to gain insights into the functioning of agroecosystems. Such understanding is very important because manipulating biotic interactions is not necessarily gentler than conventional agriculture and may also have undesirable effects such as the introduction of invasive species or loss of biodiversity.

\section{ACKNOWLEDGMENTS}

Some of the ideas presented were raised during a workshop organized by the INRA, Environment and Agronomy Department. Sabrina Gaba and Laurent Philippot are supported by INRA, Thierry Rigaud by CNRS and François Bretagnolle by University of Burgundy. This work was funded by the ANR project AgrobioSE "ANR-13-AGRO-0001-03." The revised manuscript has been corrected by Tony Tebby.

\section{REFERENCES}

Austin, M. P. (1980). Searching for a model for use in vegetation analysis. Vegetatio 42, 11-21. doi: 10.1007/BF00048865 
Bale, J. S., Van Lenteren, J. C., and Bigler, F. (2008). Biological control and sustainable food production. Philos. Trans. R. Soc. B Biol. Sci. 363, 761-776. doi: 10.1098/rstb.2007.2182

Balmer, O., Pfiffner, L., Schied, J., Willareth, M., Leimgruber, A., Luka, H., et al. (2013). Noncrop flowering plants restore top-down herbivore control in agricultural fields. Ecol. Evol. 3, 2634-2646. doi: 10.1002/ ece 3.658

Bardgett, R. D., Bowman, W. D., Kaufmann, R., and Schmidt, S. K. (2005). A temporal approach to linking aboveground and belowground ecology. Trends Ecol. Evol. 20, 634-641. doi: 10.1016/j.tree.2005.08.005

Bateman, I. J., Harwood, A. R., Mace, G. M., Watson, R. T., Abson, D. J., Andrews, B., et al. (2013). Bringing ecosystem services into economic decisionmaking: land use in the united kingdom. Science 341, 45-50. doi: 10.1126/science. 1234379

Bianchi, F. J. J. A., Booij, C. J. H., and Tscharntke, T. (2006). Sustainable pest regulation in agricultural landscapes: a review on landscape composition, biodiversity and natural pest control. Proc. R. Soc. Lond. B 273, 1715-1727. doi: 10.1098/rspb.2006.3530

Bommarco, R., Kleijn, D., and Potts, S. G. (2013). Ecological intensification: harnessing ecosystem services for food security. Trends Ecol. Evol. 28, 230-238. doi: 10.1016/j.tree.2012.10.012

Bonny, S. (2011). Ecologically intensive agriculture: nature and challenges. Cahiers Agric. 20, 451-462. doi: 10.1684/agr.2011.0526

Brown, M. W. (2012). Role of biodiversity in integrated fruit production in eastern North American orchards. Agric. For. Entomol. 14, 89-99. doi: 10.1111/j.14619563.2011.00540.x

Cardinale, B. J., Duffy, J. E., Gonzalez, A., Hooper, D. U., Perrings, C., Venail, P., et al. (2012). Biodiversity loss and its impact on humanity. Nature 486, 59-67. doi: $10.1038 /$ nature 11148

Carvalheiro, L. G., Veldtman, R., Schenkute, A. G., Tesfay, G. B., Pirk, C. W. W., Donaldson, J. C., et al. (2011). Natural and within-farmland biodiversity enhances crop productivity. Ecol. Lett. 14, 251-259. doi: 10.1111/j.14610248.2010.01579.x

Cassman, K. G. (1999). Ecological intensification of cereal production systems: yield potential, soil quality, and precision agriculture. Proc. Natl. Acad. Sci. U.S.A. 96, 5952-5959. doi: 10.1073/pnas.96.11.5952

Cassman, K. G. (2008). Scientific challenges underpinning the food-versus-fuel debate. NABC Report 20, 171-178.

Chadès, I., Mcdonald-Maden, E., Mccarthy, M. A., Wintle, B., Linkie, M., and Possingham, H. (2008). When to stop managing or surveying cryptic threatened species. Proc. Natl. Acad. Sci. U.S.A. 105, 13936-13940. doi: 10.1073/pnas. 0805265105

Chaplin-Kramer, R., O’Rourke, M. E., Blitzer, E. J., and Kremen, C. (2011). A metaanalysis of crop pest and natural enemy response to landscape complexity. Ecol. Lett. 14, 922-932. doi: 10.1111/j.1461-0248.2011.01642.x

Constanza, R., dArge, R., deGroot, R., Farber, S., Grasso, M., Hannon, B., et al. (2007). The value of the world's ecosystem services and natural capital. Nature 387, 253-260. doi: 10.1038/387253a0

Decaestecker, E., Gaba, S., Raeymaekers, J. A. M., Stoks, R., Van Kerckhoven, L., Ebert, D., et al. (2007). Host-parasite 'Red Queen' dynamics archived in pond sediment. Nature 450, 870-873. doi: 10.1038/ nature06291

Diaz, S., Lavorel, S., De Bello, F., Quetier, F., Grigulis, K., and Robson, M. T. (2007). Incorporating plant functional diversity effects in ecosystem service assessments. Proc. Natl. Acad. Sci. U.S.A. 104, 20684-20689. doi: 10.1073/pnas.0704716104

Doré, T., Makowski, D., Malezieux, E., Munier-Jolain, N., Tchamitchian, M., and Tittonell, P. (2011). Facing up to the paradigm of ecological intensification in agronomy: revisiting methods, concepts and knowledge. Eur. J. Agron. 34, 197-210. doi: 10.1016/j.eja.2011.02.006

Ebert, D. (1998). Evolution - Experimental evolution of parasites. Science 282, 1432-1435. doi: 10.1126/science.282.5393.1432

Ekstrom, G., and Ekbom, B. (2011). Pest control in agro-ecosystems: an ecological approach. CRC. Crit. Rev. Plant Sci. 30, 74-94. doi: 10.1080/07352689.2011. 554354

Gaba, S., Fried, G., Kazakou, E., Chauvel, B., and Navas, M.-L. (2014). Agroecological weed control using a functional approach: a review of cropping systems diversity. Agron. Sustain. Dev. 34, 103-119. doi: 10.1007/s13593-0130166-5
Gabriel, D., Sait, S. M., Hodgson, J. A., Schmutz, U., Kunin, W. E., and Benton, T. G. (2010). Scale matters: the impact of organic farming on biodiversity at different spatial scales. Ecol. Lett. 13, 858-869. doi: 10.1111/j.1461-0248.2010. 01481.x

Gans, C. (2005). Checklist and bibliography of the Amphisbaenia of the world. Bull. Am. Mus. Nat. Hist. 289, 7-130. doi: 10.1206/0003-0090(2005)289\%3C0001: CABOTA\%3E2.0.CO;2

Garnett, T., Appleby, M. C., Balmford, A., Bateman, I. J., Benton, T. G., Bloomer, P., et al. (2013). Sustainable intensification in agriculture: premises and policies. Science 341, 33-34. doi: 10.1126/science.1234485

Garnier, E., Lavorel, S., Ansquer, P., Castro, H., Cruz, P., Dolezal, J., et al. (2007). Assessing the effects of land-use change on plant traits, communities and ecosystem functioning in grasslands: a standardized methodology and lessons from an application to 11 European sites. Ann. Bot. 99, 967-985. doi: $10.1093 / \mathrm{aob} / \mathrm{mcl} 215$

Gilligan, C. A. (2008). Sustainable agriculture and plant diseases: an epidemiological perspective. Philos. Trans. R. Soc. B Biol. Sci. 363, 741-759. doi: 10.1098/rstb.2007.2181

Griffiths, B. S., Ritz, K., Bardgett, R. D., Cook, R., Christensen, S., Ekelund, F., et al. (2000). Ecosystem response of pasture soil communities to fumigationinduced microbial diversity reductions: an examination of the biodiversityecosystem function relationship. Oikos 90, 279-294. doi: 10.1034/j.16000706.2000.900208.x

Haas, D., and Defago, G. (2005). Biological control of soil-borne pathogens by fluorescent pseudomonads. Nat. Rev. Microbiol. 3, 307-319. doi: 10.1038/nrmicrol129

Haines-Young, R., and Potschin, M. (2010). "The links between biodiversity, ecosystem services and human well-being," in Ecosystem Ecology: A New Synthesis, eds D. Raffaelli and C. Frid (Cambridge: Cambridge University Press), $1-31$.

Hanski, I., and Woiwod, I. (1991). Delayed density-dependence. Nature 350, 28. doi: $10.1038 / 350028 \mathrm{a} 0$

Harman, G. E. (2006). Overview of mechanisms and uses of Trichoderma spp. Phytopathology 96, 190-194. doi: 10.1094/PHYTO-96-0190

Herrera, J. M., and Doblas-Miranda, E. (2013). Land-cover change effects on trophic interactions: current knowledge and future challenges in research and conservation. Basic Appl. Ecol. 14, 1-11. doi: 10.1016/j.baae.2012.11.008

Hinsinger, P., Betencourt, E., Bernard, L., Brauman, A., Plassard, C., Shen, J., et al. (2011). P for two, sharing a scarce resource: soil phosphorus acquisition in the rhizosphere of intercropped species. Plant Physiol. 156, 1078-1086. doi: 10.1104/pp.111.175331

Hoddle, M. S., Van Driesche, R. G., and Sanderson, J. P. (1998). Biology and use of the whitefly parasitoid Encarsia formosa. Annu. Rev. Entomol. 43, 645-669. doi: 10.1146/annurev.ento.43.1.645

Hol, W. H. G., De Boer, W., Termorshuizen, A. J., Meyer, K. M., Schneider, J. H. M., Van Dam, N. M., et al. (2013). Reduction of rare soil microbes modifies plant-herbivore interactions. Ecol. Lett. 13, 292-301. doi: 10.1111/j.14610248.2009.01424.x

Isbell, F., Calcagno, V., Hector, A., Connolly, J., Harpole, W. S., Reich, P. B., et al. (2011). High plant diversity is needed to maintain ecosystem services. Nature 477, 199-202. doi: 10.1038/nature 10282

Jonason, D., Andersson, G. K. S., Ockinger, E., Rundlof, M., Smith, H. G., and Bengtsson, J. (2011). Assessing the effect of the time since transition to organic farming on plants and butterflies. J. Appl. Ecol. 48, 543-550. doi: 10.1111/j.13652664.2011.01989.x

Kearney, M., Porter, W. P., Williams, C., Ritchie, S., and Hoffmann, A. A. (2009). Integrating biophysical models and evolutionary theory to predict climatic impacts on species' ranges: the dengue mosquito Aedes aegypti in Australia. Funct. Ecol. 23, 528-538. doi: 10.1111/j.1365-2435.2008.01538.x

Koskella, B., and Lively, C. M. (2007). Advice of the rose: experimental coevolution of a trematode parasite and its snail host. Evolution 61, 152-159. doi: 10.1111/j.1558-5646.2007.00012.x

Kremen, C., Williams, N. M., Bugg, R. L., Fay, J. P., and Thorp, R. W. (2004) The area requirements of an ecosystem service: crop pollination by native bee communities in California. Ecol. Lett. 7, 1109-1119. doi: 10.1111/j.14610248.2004.00662.x

Lamarque, P., Quétier, F., and Lavorel, S. (2011). The diversity of the ecosystem services concept and its implications for their assessment and management. $C$. R. Biol. 334, 441-449. doi: 10.1016/j.crvi.2010.11.007 
Lavorel, S., and Garnier, E. (2002). Predicting changes in community composition and ecosystem functioning from plant traits: revisiting the Holy Grail. Funct. Ecol. 16, 545-556. doi: 10.1046/j.1365-2435.2002.00664.x

Lavorel, S., Grigulis, K., Lamarque, P., Colace, M.-P., Garden, D., Girel, J., et al. (2011). Using plant functional traits to understand the landscape-scale distribution of multiple ecosystem services. J. Ecol. 99, 135-147. doi: 10.1111/j.13652745.2010.01753.x

Letourneau, D. K., Armbrecht, I., Salguero Rivera, B., Montoya Lerma, J., Jimenez Carmona, E., Constanza Daza, M., et al. (2011). Does plant diversity benefit agroecosystems? A synthetic review. Ecol. Appl. 21, 9-21. doi: 10.1890/092026.1

Macfadyen, S., Gibson, R. H., Symondson, W. O. C., and Memmott, J. (2011). Landscape structure influences modularity patterns in farm food webs: consequences for pest control. Ecol. Appl. 21, 516-524. doi: 10.1890/09-2111.1

Maherali, H., and Klironomos, J. N. (2007). Influence of Phylogeny on fungal community assembly and ecosystem functioning. Science 316, 1746-1748. doi: $10.1126 /$ science. 1143082

May, R. M. (1972). Will a large complex system be stable? Nature 238, 413-414. doi: $10.1038 / 238413 \mathrm{a} 0$

Mcneely, J. A., and Scherr, S. J. (2003). Ecoagriculture, Strategies to Feed the World and Save Wild Biodiversity. Washington, DC: Island Press.

Mendes, R., Kruijt, M., De Bruijn, I., Dekkers, E., Van Der Voort, M., Schneider, J. H. M., et al. (2011). Deciphering the rhizosphere Microbiome for disease-suppressive bacteria. Science 332, 1097-1100. doi: 10.1126/science. 1203980

Menendez, R., Megias, A. G., Hill, J. K., Braschler, B., Willis, S. G., Collingham, Y., et al. (2006). Species richness changes lag behind climate change. Proc. R. Soc. B Biol. Sci. 273, 1465-1470. doi: 10.1098/rspb.2006.3484

Millennium Ecosystem Assessment. (2005). Ecosystems and Human Well-Being. A Framework For Assessment. Washington, DC: Island Press.

Mitsch, W. J., and Jorgensen, S. E. (2003). Ecological engineering: a field whose time has come. Ecol. Eng. 20, 363-377. doi: 10.1016/j.ecoleng.2003.05.001

Montoya, J. M., Pimm, S. L., and Sole, R. V. (2006). Ecological networks and their fragility. Nature 442, 259-264. doi: 10.1038/nature04927

Norberg, J., Urban, M. C., Vellend, M., Klausmeier, C. A., and Loeuille, N. (2012). Eco-evolutionary responses of biodiversity to climate change. Nat. Clim. Chang. 2, 747-751. doi: 10.1038/nclimate1588

Northfield, T. D., Snyder, G. B., Ives, A. R., and Snyder, W. E. (2010). Niche saturation reveals resource partitioning among consumers. Ecol. Lett. 13, 338-348. doi: 10.1111/j.1461-0248.2009.01428.x

Perdikis, D., Fantinou, A., and Lykouressis, D. (2011). Enhancing pest control in annual crops by conservation of predatory Heteroptera. Biol. Control 59, 13-21. doi: 10.1016/j.biocontrol.2011.03.014

Philippot, L., and Hallin, S. (2011). Towards food, feed and energy crops mitigating climate change. Trends Plant Sci. 16, 476-480. doi: 10.1016/j.tplants.2011. 05.007

Philippot, L., Raaijmakers, J. M., Lemanceau, P., and Van Der Putten, W. H. (2013a). Going back to the roots: the microbial ecology of the rhizosphere. Nat. Rev. Microbiol. 11, 789-799. doi: 10.1038/nrmicro3109

Philippot, L., Spor, A., Henault, C., Bru, D., Bizouard, F., Jones, C. M., et al. (2013b). Loss in microbial diversity affects nitrogen cycling in soil. ISME J. 7, 1609-16019. doi: 10.1038/ismej.2013.34

Poisot, T., Thrall, P. H., and Hochberg, M. E. (2012). Trophic network structure emerges through antagonistic coevolution in temporally varying environments. Proc. R. Soc. B Biol. Sci. 279, 299-308. doi: 10.1098/rspb.2011.0826

Power, A. G. (2010). Ecosystem services and agriculture: tradeoffs and synergies. Philos. Trans. R. Soc. B Biol. Sci. 365, 2959-2971. doi: 10.1098/rstb.2010.0143

Pretty, J. (2008). Agricultural sustainability: concepts, principles and evidence. Philos. Trans. R. Soc. B Biol. Sci. 363, 447-465. doi: 10.1098/rstb.2007.2163

Ratnadass, A., Fernandes, P., Avelino, J., and Habib, R. (2012). Plant species diversity for sustainable management of crop pests and diseases in agroecosystems: a review. Agron. Sustain. Dev. 32, 273-303. doi: 10.1007/s13593-0110022-4

Rex Consortium. (2013). Heterogeneity of selection and the evolution of resistance. Trends Ecol. Evol. 28, 110-118. doi: 10.1016/j.tree.2012.09.001

Rooney, N., and Mccann, K. (2011). Integrating diversity, food web structure and stability. Trends Ecol. Evol. 27, 40-46. doi: 10.1016/j.tree.2011.09.001

Rua, M. A., Mcculley, R. L., and Mitchell, C. E. (2013). Fungal endophyte infection and host genetic background jointly modulate host response to an aphid-transmitted viral pathogen. J. Ecol. 101, 1007-1018. doi: 10.1111/13652745.12106

Ryu, C.-M., Farag, M. A., Hu, C.-H., Reddy, M. S., Wei, H.-X., Paré, P. W., et al. (2003). Bacterial volatiles promote growth in Arabidopsis. Proc. Natl. Acad. Sci. U.S.A. 100, 4927-4932. doi: 10.1073/pnas.0730845100

Schausberger, P., and Walzer, A. (2001). Combined versus single species release of predaceous mites: predator-predator interactions and pest suppression. Biol. Control 20, 269-278. doi: 10.1006/bcon.2000.0908

Shennan, C. (2008). Biotic interactions, ecological knowledge and agriculture. Philos. Trans. R. Soc. B Biol. Sci. 363, 717-739. doi: 10.1098/rstb.20 07.2180

Snyder, G. B., Finke, D. L., and Snyder, W. E. (2008). Predator biodiversity strengthens aphid suppression across single- and multiple-species prey communities. Biol. Control 44, 52-60. doi: 10.1016/j.biocontrol.2007.09.006

Stouffer, D. B., and Bascompte, J. (2011). Compartmentalization increases food-web persistence. Proc. Natl. Acad. Sci. U.S.A. 108, 3648-3652. doi: $10.1073 /$ pnas. 1014353108

Subbarao, G. V., Nakahara, K., Hurtado, M. P., Ono, H., Moreta, D. E. Salcedo, A. F., et al. (2009). Evidence for biological nitrification inhibition in Brachiaria pastures. Proc. Natl. Acad. Sci. U.S.A. 106, 17302-17307. doi: 10.1073/pnas.0903694106

Symondson, W. O. C., Sunderland, K. D., and Greenstone, M. H. (2002). Can generalist predators be effective biocontrol agents? Annu. Rev. Entomol. 47, 561-594. doi: 10.1146/annurev.ento.47.091201.145240

Takizawa, T., and Snyder, W. E. (2011). Predator biodiversity increases the survivorship of juvenile predators. Oecologia 166, 723-730. doi: 10.1007/s00442-0101891-y

Thebault, E., and Fontaine, C. (2010). Stability of ecological communities and the architecture of mutualistic and trophic networks. Science 329, 853-856. doi: $10.1126 /$ science. 1188321

Thies, C., and Tscharntke, T. (1999). Landscape structure and biological control in agroecosystems. Science 285, 893-895. doi: 10.1126/science.285.5429.893

Thompson, J. N. (2005). The Geographic Mosaic of Coevolution. Chicago, IL: University of Chicago Press.

Thrall, P. H., Laine, A.-L., Ravensdale, M., Nemri, A., Dodds, P. N., Barrett, L. G., et al. (2012). Rapid genetic change underpins antagonistic coevolution in a natural host-pathogen metapopulation. Ecol. Lett. 15, 425-435. doi: 10.1111/j.1461-0248.2012.01749.x

Tilman, D., Wedin, D., and Knops, J. (1996). Productivity and sustainability influenced by biodiversity in grassland ecosystems. Nature 379, 718-720. doi 10.1038/379718a0

Tixier, P., Duyck, P. F., Côte, F. X., Caron-Lormier, G., and Malézieux, E. (2013a). Food web-based simulation for agroecology. Agron. Sustain. Dev. 33, 663-670 doi: 10.1007/s13593-013-0139-8

Tixier, P., Peyrard, N., Aubertot, J.-N., Gaba, S., Radoszycki, J., Caron-Lormier, G., et al. (2013b). Modelling interaction networks for enhanced ecosystem services in agroecosystems. Adv. Ecol. Res. 49, 437-480. doi: 10.1016/B978-0-12-4200029.00007-X

Torsvik, V., Goksoyr, J., and Daae, F. L. (1990). High diversity in DNA of soil bacteria. Appl. Environ. Microbiol. 56, 782-787.

Tscharntke, T., Clough Y., Wanger, T. C., Jackson, L., Motzke, I., Perfecto, I., et al. (2012). Global food security, biodiversity conservation and the future of agricultural intensification. Biol. Conserv. 151, 53-59. doi: 10.1016/j.biocon.2012.01.068

Veres, A., Petit, S., Conord, C., and Lavigne, C. (2011). Does landscape composition affect pest abundance and their control by natural enemies? A review. Agric. Ecosyst. Environ. 138, 10-16. doi: 10.1016/j.agee.2011.05.027

Wangersky, P. J., and Cunningham, W. J. (1957). Time lag in prey-predator population models. Ecology 38, 136-139. doi: 10.2307/1932137

Wardle, D. A., Bardgett, R. D., Klironomos, J. N., Setala, H., Van Der Putten, W. H., and Wall, D. H. (2004). Ecological linkages between aboveground and belowground biota. Science 304, 1629-1633. doi: 10.1126/science. 1094875

Werling, B. P., and Gratton, C. (2010). Local and broadscale landscape structure differentially impact predation of two potato pests. Ecol. Appl. 20, 1114-1125. doi: 10.1890/09-0597.1

Whitman, W. B., Coleman, D. C., and Wiebe, W. J. (1998). Prokaryotes: the unseen majority. Proc. Natl. Acad. Sci. U.S.A. 95, 6578-6583. doi: 10.1073/pnas.95.12.6578 
Williams, B. K. (2007). Optimal management of non-Markovian biological populations. Ecol. Modelling 200, 234-242. doi: 10.1016/j.ecolmodel.2006.07.039

Wittebolle, L., Marzorati, M., Clement, L., Balloi, A., Daffonchio, D., Heylen, K., et al. (2009). Initial community evenness favours functionality under selective stress. Nature 458, 623-626. doi: 10.1038/nature07840

Yachi, S., and Loreau, M. (1999). Biodiversity and ecosystem productivity in a fluctuating environment: the insurance hypothesis. Proc. Natl. Acad. Sci. U.S.A. 96, 1463-1468. doi: 10.1073/pnas.96.4.1463

Conflict of Interest Statement: The authors declare that the research was conducted in the absence of any commercial or financial relationships that could be construed as a potential conflict of interest.
Received: 15 April 2014; accepted: 15 June 2014; published online: 30 June 2014. Citation: Gaba S, Bretagnolle F, Rigaud T and Philippot L (2014) Managing biotic interactions for ecological intensification of agroecosystems. Front. Ecol. Evol. 2:29. doi: $10.3389 /$ fevo.2014.00029

This article was submitted to Agroecology and Land Use Systems, a section of the journal Frontiers in Ecology and Evolution.

Copyright $\odot 2014$ Gaba, Bretagnolle, Rigaud and Philippot. This is an open-access article distributed under the terms of the Creative Commons Attribution License (CC BY). The use, distribution or reproduction in other forums is permitted, provided the original author(s) or licensor are credited and that the original publication in this journal is cited, in accordance with accepted academic practice. No use, distribution or reproduction is permitted which does not comply with these terms. 